5-1-2017

\title{
Asymmetry in Inflation Targeting
}

\author{
Erhan Aslanoğlu \\ Piri Reis University, easlanoglu@pirireis.edu.tr \\ Pinar Deniz \\ Marmara University, pinar.deniz@marmara.edu.tr
}

Follow this and additional works at: https://ecommons.luc.edu/meea

\section{Recommended Citation}

Aslanoğlu, Erhan and Deniz, Pinar, "Asymmetry in Inflation Targeting". Topics in Middle Eastern and North African Economies, electronic journal, 19, 1, Middle East Economic Association and Loyola University Chicago, 2017, http://www.luc.edu/orgs/meea/

This Article is brought to you for free and open access by the Journals and Magazines at Loyola eCommons. It has been accepted for inclusion in Topics in Middle Eastern and North African Economies by an authorized administrator of Loyola eCommons. For more information, please contact ecommons@luc.edu. cc) (i) (2)

This work is licensed under a Creative Commons Attribution-Noncommercial-No Derivative Works 3.0 License. (C) 2017 The Authors 


\title{
Asymmetry in inflation targeting
}

\author{
Erhan Aslanoğlu ${ }^{1}$ \\ Pinar Deniz ${ }^{2}$
}

\begin{abstract}
Following the world financial crisis beginning in the last quarter of 2008, aggregate demand and commodity prices have declined sharply leading to a fast decline in world inflation. This different and new period reflects the rise in risk appetite leading to high fluctuations in the short term capital flows. World central banks revised their monetary policy to the changing conditions taking into account financial stability.

In 2002, Turkish central bank adopted inflation targeting (in the implicit form) to maintain price stability. After 2008, following the developments in global markets, Turkish economy reflects similar characteristics in the form of decline in inflation rates. Together with the changes in the economic conditions, estimating monetary policy models in the form of constant-coefficient and symmetric specification may lead to erroneous interpretations. This study analyze the existence of structural break(s) and asymmetric behavior for the 2003-2016 period. The paper also examines the monetary policy model under New Keynesian fashion. Turkish monetary policy investigated for the period presents October 2009 as the break point under different models and structural break tests. Asymmetric reactions to interest rate, output and exchange rate are observed suggesting the different monetary preferences of the central bank of Turkey.
\end{abstract}

Keywords: Inflation targeting, Turkey, structural break, asymmetry, new Keynesian DSGE model

JEL Classification: C32, E31, E52

\footnotetext{
${ }^{1}$ Piri Reis University, Department of Economics and Finance, E-mail: easlanoglu@ pirireis.edu.tr

${ }^{2}$ Marmara University, Department of Economics, E-mail: pinar.deniz@marmara.edu.tr
} 


\section{Introduction}

The rise of public and private indebtedness and hence capital flows and the fall of the desire for government intervention after the globalization of 1990s have led to a dramatic change in the economic policy worldwide. Real economic policy lost its importance and monetary policy became the main economic policy due to the massive capital accumulation and its power. The main objective of Central Bank of Turkey is to achieve and maintain price stability through inflation targeting policy. After the structural transformation process, inflation targeting regime was adopted by 2002. After an implicit inflation targeting period between 2002 and 2005, a formal and full-fledged inflation targeting regime was carried out after 2006. Inflation rates started to decline immediately from around $80 \%$ and reached levels around $10 \%$ by 2004 . Without backpedaling, the successful monetary policy management continues with the contribution of central bank independence, which basically requires prohibition of granting advances to and purchasing debt instruments of the public institutions.

Following the success of persistently low inflation rates, Turkish economy reflects high growth rates up to the global crisis, which extended its global effects in late-2008. Following the global crisis, the monetary policy seems to lose its strong stance which is also highlighted in the relevant literature. After the specification of monetary policy rule of central banks by Taylor (1993), several analyses were applied to many countries in order to examine whether the monetary policy makers follow Taylor's rule, which specifies the policy rate to be determined by inflation gap and output gap. However, central banks' monetary policy decisions may change over time or different economic conditions. Hence, structural breaks and asymmetric models for monetary policy are highlighted in the literature. Gürkaynak et al. (2015) present a broad examination of 2003-2014 period of Turkish economy and the monetary policy and observe a structural break in the end of 2009 , referring to the global financial crisis, using Chow tests suggesting the loss of nominal anchor by the Central Bank of Turkey after the break date. Globally, the US subprime mortgage crisis that took place from 2007-end to mid-2009 and the Euro crisis that began by 2009 affected several commercially and financially close markets including Turkish economy. 2000s were the years of tremendous rise in commodity prices argued to be resulting from the large demand rise of emerging economies. However, after the collapse of credit markets during 2008 and early 2009 , the commodity prices, especially oil prices, reflect an epic decline with the fall in the 
demand of emerging economies. In such a period, Turkish economy reflect a decline in GDP growth rates, a shift in the long run export levels and a rise in exchange rate volatility. Global developments affecting all economies may also lead to changes in the domestic monetary policy rules. The importance of asymmetric monetary policy rule is recently highlighted by the speech of Fed Chair Janet Yellen (2015 May) regarding the effectiveness of monetary policy changes in the vicinity of zero lower bound.

The aim of this paper is to examine the asymmetric behavior and the structural break of the Turkish monetary policy for 2003-2016 period, which includes several transformations domestically and globally. Existence of break is investigated using several breakpoint tests and the asymmetric behavior is investigated by allowing for changes in the coefficients of the explanatory variables in different regimes. Empirical findings prove the existence of asymmetry and structural break for the relevant period. The literature on asymmetric monetary policies is not new. Several papers suggest the inflationary bias in the existence of asymmetric monetary policies where the policymakers decide differently on expansionary and contractionary periods (Jordan, 1998; Ruge-Murcia, 1999; Cukierman, 1999). Hasanov and Omay (2008) using Turkish monthly data for the period of 1990-2000 examines the asymmetric monetary policy rule for the expansion and recession periods based on Bec et al. (2002). In the empirical investigation, they observe that the central bank reacts more aggressively towards output stabilization during periods of recession than periods of expansion.

There are also several papers examining the asymmetric behavior in the emerging or developing countries. Vasicek (2012), estimating asymmetry in the Taylor rule for Czech Republic, Hungary, and Poland, observes that there are no asymmetries for the inflation but asymmetries exist for the output gap. Similarly, Sznajderska (2014) examines the asymmetric effects in the Polish monetary policy rule using inflation gap and output gap as the threshold variables. It is observed that central bank reacts more strongly to the level of inflation when it is relatively high. Benlialper et al. (2015) differently from the literature, examine 12 developing country central bank's asymmetric preferences with respect to exchange rate rather than output gap or inflation. The data period selected for each country is 2002-2008, the period that the countries are implementing inflation targeting policy. They observe that the 
central banks tolerate appreciation and small depreciations but respond strongly when depreciation is above a specific threshold level.

The empirical findings on asymmetric monetary reaction functions on developed countries dates back to earlier. Surico (2003) examines a nonlinear reaction function of ECB comparing it with Bundesbank and FED counterparts for the narrow period of 1997-2002 using monthly data. They do not detect existence of asymmetric behavior for the inflation but using nonlinear model argue that the policy response to inflation is stronger in boom periods than in recession times, whereas they observe an asymmetry in output gap in the way that contraction times require stronger intervention of monetary policy than expansion periods. The study of Bec et al. (2002), which becomes one of the basics in the asymmetric models, examine the asymmetries in monetary policy reaction function of the US, French and German central banks. Employing generalized method of moments (GMM) technique, they observe that each central bank reacts differently from the other in recession and expansion periods. As one of the recent examples on developed economies, Klose (2011) identifies asymmetries in ECB behavior using standard Taylor reaction functions and find that when output and inflation are both above or below target, the reaction is stronger for smaller deviations. Similar to our methodology, Komlan (2013) examines the asymmetric and nonlinear behavior of the reaction of the monetary policy of Bank of Canada using inflation gap and output gap as the thresholds. He observes an asymmetric behavior suggesting that the reaction function of the Bank of Canada can be better modeled through a nonlinear model.

In the light of the relevant literature, we also try to check whether coefficients of the Taylor rule are constant using a DSGE model based on Justiniano and Preston (2010). The estimation results suggest a change in the monetary policy parameters however the change is lower than the empirical findings obtained from empirical estimations for the single equation model and from the literature.

Differently from the main trend of taking recession and contraction periods as the thresholds, in the literature of asymmetric effects of the reaction function of the central banks, this study concentrates on the asymmetric effects of global and domestic price movements. The argument for the focus on price movements is to investigate the effects of changing global prices for the period in question. Moreover, a basic DSGE model is estimated to test the 
potential parameter-nonconstancy under a modeling framework. The paper is constructed as follows. The following section discusses the monetary policy rule in Turkey. Section 3 explains the asymmetric behaviour and the parameter-constancy of Taylor Rule model reporting the OLS estimations with asymmetry and structural break tests. Section 4 describes Justiniano and Preston (2010) small open economy DSGE model, the dataset observed in the model, the calibration. Section 5 explains the estimation and results. The final section concludes the paper.

\section{Brief History of Monetary Policy in Turkey}

The monetary policy of Turkish Central Bank (CBT) changes from overnight rate to 1-week repo rate after 2010 May as the liquidity conditions change. After the structural reforms, inflation targeting regime was carried out by 2002 which became explicit and formal in 2006. The main objective of the CBT is explained as achieving and maintaining price stability however, practically it is not the sole objective. Many central banks employ models that determine monetary policy not through only inflation concerns but also through indicators of output, sometimes exchange rate -especially when foreign capital flow is a crucial concernand so on. Consistent with the global examples, empirical literature on Turkish monetary policy implicitly takes into account of output and exchange rate concerns (Hasanova and Omay, 2008; Geyik, 2011; Berument and Malatyali, 2000; Berument, 2007; Ülke and Berument, 2016)

After 2002, monetary policy became very successful in Turkey in lowering inflation as observed in Figure 1, which also contributed to its credibility which further brought success to the policy-making. Following 2007, the global stance started to change with poor financial conditions, rapid decline in the commodity prices after 2009 together with the negative demand shock by the emerging markets, mainly by the BRIC economies. The US reflected the decline in commodity prices very clearly in its CPI growth rates (Figure 4). As an emerging economy, Turkey was affected significantly between 2009Q2 and 2010Q1, as depicted in Figure 1. After the globally devastating US crisis between 2007 and 2009, the Euro sovereign debt crisis deteriorated Turkish economy mainly through export markets, given in Figure 2, and capital markets, given in Figure 3. 


\section{Asymmetric Behavior and Parameter-Constancy of Taylor Rule model}

Parameter change takes place in the regression models in the existence of structural breaks and/or asymmetric conditions, which refers to parameter non-constancy under different economic circumstances. In this paper, the main idea is to test the asymmetry of the Turkish monetary policy rule in the light of recent global developments and domestic conditions.

The monetary policy is examined using OLS under 2 different Taylor rule models. The first model is defined with the determinants of inflation $\left(\pi_{t}\right)$ and growth rate $\left(g_{t}\right)$, the second model additionally includes deviation of exchange rate from its nonlinear trend $\left(\tilde{X} R_{t}\right)$. Deviation from nonlinear trend is obtained by HP filter. The dataset have monthly frequency. Output is measured by industrial production level. Interest rate is policy rate and inflation is annual CPI growth rates. All dataset are obtained from CBT.

\section{Model 1:}

$i_{t}=i_{0}+\delta_{1} \pi_{t}+\delta_{2} g_{t}+\varepsilon_{t}$

\section{Model 2:}

$$
i_{t}=i_{0}+\delta_{1} \pi_{t}+\delta_{2} g_{t}+\delta_{3} \tilde{X} R_{t}+\varepsilon_{t}
$$

To examine the OLS regression models, stationarity must be satisfied. In Table 1, stationarity of variables are tested using Augmented Dickey Fuller (ADF) and Phillips Perron (PP) unit root tests. $\mathrm{ADF}$ and $\mathrm{PP}$ tests for interest rate and exchange rate deviation reject the null hypothesis of existence of unit root. Industrial production growth and inflation rates only cannot reject existence of unit root in constant and trend case of ADF test and PP, successively. Overall, variables are observed to be stationary.

Table 1: Unit Root Tests

\begin{tabular}{ccccc}
\hline & \multicolumn{2}{c}{ ADF test } & \multicolumn{2}{c}{ PP } \\
\cline { 2 - 5 } & constant & constant \& trend & constant & constant \& trend \\
\hline$i_{t}$ & $-4.655^{*}$ & $-4.045^{*}$ & $-4.548^{*}$ & $-3.522^{*}$ \\
& $(0.000)$ & $(0.009)$ & $(0.000)$ & $(0.040)$ \\
& $-2.979 *$ & -3.083 & $-6.343^{*}$ & $-6.558^{*}$ \\
$g_{t}$ & $(0.039)$ & $(0.114)$ & $(0.000)$ & $(0.000)$
\end{tabular}




$\begin{array}{ccccc}\pi_{t} & -3.774 * & -4.835^{*} & -3.360 * & -2.999 \\ & (0.004) & (0.001) & (0.014) & (0.136) \\ \tilde{X} R_{t} & -4.973^{*} & -4.958^{*} & -4.041^{*} & -4.032^{*} \\ & (0.000) & (0.000) & (0.002) & (0.001)\end{array}$

Note: (*) denotes rejection of the null hypothesis at 5\% significance level.

After providing evidence of stationarity for all variables, we employed two different breakpoint tests to observe whether there is a significant break for the period. Structural break tests dates back to Chow (1960) F statistics. However, the limitation of Chow test is that the breakpoint must be known a priori. Quandt (1960) modifies Chow test to consider the Fstatistic with the largest value over all possible breakpoints. Thus, the test determines the breakpoint without any specification a priori. Andrews (1993) and Andrews and Ploberger (1994) provide critical values for the new test. Bai (1997) and Bai and Perron (1998, 2003) extend the Quandt-Andrews test by allowing for multiple unknown breakpoints. Table 2 gives the breakpoints for the two models. Both Quandt-Andrews and Bai and Perron $(1998,2003)$ tests suggest October 2009 as the breakpoint for the whole dataset of 2003M01-2016M04.

Table 2: Breakpoint Tests

\begin{tabular}{lll}
\hline & Model 1 & Model 2 \\
\hline Quandt-Andrews & $2009 \mathrm{M} 10$ & $2009 \mathrm{M} 10$ \\
Bai-Perron tests & $2009 \mathrm{M} 10$ & $2009 \mathrm{M} 10$
\end{tabular}

Note: The options selected for Bai-Perron multiple breakpoint test are maximum 1 globally determined break, trimming percentage of 15 , significance level of $5 \%$ and White heteroskedasticity-consistent covariances. For Quandt-Andrews unknown breakpoint test, data is trimmed by $15 \%$.

Table 3 provides the estimates of the two models for the whole period and before and after the break point of 2009 October. The first period, which ends in 2009 October reflects the inflation parameter approximately as 1.30 for both models, whereas industrial production growth parameter is comparatively very lower, around 0.18 . In the second period, inflation parameter decline severely to around 0.22 and so does industrial production growth parameter 
declines to around 0.05. Exchange rate also reflects a decline in the second period. The first look at the second period, i.e., the global financial crisis and lower global prices period, suggests that inflationary concerns have declined in the determination of monetary policy. We can argue the same suggestion for output and exchange rate concerns. However, the goodness-of-fit (R-square) of the second period is observed to be very low, around 7\%, suggesting some omitted determinants or conditions.

Table 3: Taylor Rule Estimations

\begin{tabular}{|c|c|c|c|c|}
\hline Model & Variables & 2003/01-2016/04 & 2003/01-2009/10 & 2009/11-2016/04 \\
\hline \multirow{7}{*}{ Model 1} & \multirow{2}{*}{ constant } & $-2.084 *$ & $6.93 *$ & $4.87^{*}$ \\
\hline & & $(0.863)$ & $(0.76)$ & $(0.86)$ \\
\hline & \multirow{2}{*}{ inflation } & $1.110^{\circ}$ & & 0.22 \\
\hline & & $(0.067)$ & $(0.07)$ & $(0.10)$ \\
\hline & \multirow[t]{2}{*}{ IP growth } & 0.089 & $0.16^{*}$ & $0.05 *$ \\
\hline & & $(0.049)$ & $(0.03)$ & $(0.02)$ \\
\hline & $\mathrm{R}^{2}$ & 0.67 & 0.90 & 0.07 \\
\hline \multirow{7}{*}{ Model 2} & constant & $-2.091 *$ & $6.92 *$ & $4.82^{*}$ \\
\hline & \multirow{2}{*}{ inflation } & $\begin{array}{c}(1.103) \\
1.716^{*}\end{array}$ & $\begin{array}{l}(0.72) \\
1.33^{*}\end{array}$ & $\begin{array}{c}(0.92) \\
0.22^{*}\end{array}$ \\
\hline & & $(0.099)$ & $(0.06)$ & $(0.11)$ \\
\hline & IP growth & 0.094 & $0.18^{*}$ & $0.05^{*}$ \\
\hline & $\%$ deviation of $\mathrm{XR}$ & $\begin{array}{c}(0.059) \\
2.446\end{array}$ & $\begin{array}{l}(0.03) \\
8.62 *\end{array}$ & $\begin{array}{c}(0.03) \\
-0.81\end{array}$ \\
\hline & from its nonlinear trend & (8.224) & $(4.32)$ & $(3.86)$ \\
\hline & $\mathrm{R}^{2}$ & 0.67 & 0.90 & 0.07 \\
\hline
\end{tabular}

Note: $(*)$ denotes significance at $5 \%$ significance level.

The literature, especially the recent, pays a high attention to the parameter-nonconstancy in the monetary policy rules of the central banks indicating the deficiencies and erroneous interpretations of the models which are not taking such changes into account in the empirical analysis. In order to capture whether there is an asymmetric behavior in the determination of the policy rate, we divide the model into two regimes: (i) the regime if deviation of threshold variable $\left(x_{t}\right)$ from its HP trends is negative (Regime 1), (ii) the regime if deviation of threshold variable from its HP trends is positive (Regime 2). We select two threshold variables, i.e., inflation rate and industrial production level. Equation 3 and 4 include I(.), which is an indicator function takes value one if the condition in parentheses is true and zero otherwise. Asymmetry in the monetary policy determination is examined in two models as 
shown previously in Equations (1) and (2), i.e., (i) model 1 employs inflation and industrial production growth as the explanatory variables, (ii) deviation of exchange rate from its nonlinear trend is added in model 2.

\section{Model 1:}

$i_{t}=\left(\delta_{1} \pi_{t}+\delta_{2} g_{t}\right) \cdot I\left(x_{t}<0\right)+\left(\alpha_{1} \pi_{t}+\alpha_{2} g_{t}\right) \cdot I\left(x_{t}>0\right)+\varepsilon_{t}$

\section{Model 2:}

$i_{t}=\left(\delta_{1} \pi_{t}+\delta_{2} g_{t}+\delta_{3} \tilde{X} R_{t}\right) \cdot I\left(x_{t}<0\right)+\left(\alpha_{1} \pi_{t}+\alpha_{2} g_{t}+\delta_{3} \tilde{X} R_{t}\right) \cdot I\left(x_{t}>0\right)+\varepsilon_{t}$

Estimation results of the asymmetric behavior are given in Tables 4, 5 and 6, successively for the whole period and the period before and after 2009M10. For the whole period model, exchange rate deviation for the second model is observed to be insignificant and inflation reflects positive and significant effects for both models, regimes and threshold variables. For the models of inflation gap as the threshold for asymmetry, industrial production growth has positive impact in regime 1 of the model 1; and for the models taking output gap as the threshold, the impact of IP growth is positively significant for regime 2. Considering the asymmetry of the monetary policy reaction, the empirical findings reflect that the periods of lower inflation rate have looser monetary policy than the degree of tightening in the higher inflation periods. Generally, the examples in the relevant literature reflect opposite results, that is, monetary policy is more aggressive to positive inflation deviations than negative ones. Our opposite findings (the result is consistent with models for before and after break point given in Tables 5 and 6) may be attributed to the peculiar economic and political circumstances of Turkey regarding the period in question. The significantly and persistently lower inflationary period after 2003 enable the monetary policy makers to cut down interest rates are more and more as with the decline in the risk premium which involves lower and lower inflationary expectations. We also observe this higher reaction to lower inflation period in the period before structural break. The difference between the two regimes are also tested via Wald statistics for $H_{0}: \delta_{1}=\alpha_{1}$, which is rejected significantly at $10 \%$ significance level.

Table 4 shows that, for the models of output gap as the threshold variable, monetary policy reacts to IP growth positively and significantly for the periods of positive output gap, whereas the reaction is insignificant for the negative output gap periods. This finding suggests that monetary policy is not concerned with negative output gap periods but positive ones so as to 
cool down the economy in the times of expansion. However, the findings relevant to the whole period can be criticized since it captures different economic conditions. If we consider the period before the structural break of 2009, which we may refer as global financial crisis period as mentioned by Gürkaynak et al. (2015), we observe significant and positive reaction to IP growth for both regimes and both models, given in Table 5. Moreover, different from the whole period models, we observe that regime 1 periods reflect higher impacts compared to regime 2 , suggesting that the negative output gap periods are more of a concern by the policy makers compared to positive output gap periods. Hence, it can be argued that economic growth is desired more than its inflationary (bubble) effects.

Table 4: Estimation Results for the asymmetric behavior (2003M01-2016M04)

\begin{tabular}{lcccc}
\hline & \multicolumn{2}{c}{ Model 1 } & \multicolumn{2}{c}{ Model 2 } \\
Threshold & inflation & IP & inflation rate & IP \\
\hline Rariable: & rate & & & \\
\hline Regime 1 & & & $2.320^{*}$ & $1.811^{*}$ \\
Inflation rate & $2.302^{*}$ & $1.830^{*}$ & $(0.142)$ & $(0.111)$ \\
Annual IP growth & $(0.147)$ & $(0.102)$ & 0.083 & 0.041 \\
Exchange rate & $0.100^{*}$ & -0.018 & $(0.065)$ & $(0.080)$ \\
deviation & $(0.052)$ & $(0.055)$ & -6.828 & 16.427 \\
\hline Regime 2 & & & $(11.455)$ & $(14.202)$ \\
\hline Inflation rate & $1.835^{*}$ & $1.674^{*}$ & $1.830^{*}$ & $1.669^{*}$ \\
& $(0.070)$ & $(0.066)$ & $(0.065)$ & $(0.075)$ \\
Annual IP growth & -0.037 & $0.278^{*}$ & -0.023 & $0.301^{*}$ \\
Exchange rate & $(0.073)$ & $(0.091)$ & $(0.072)$ & $(0.091)$ \\
deviation & & & 11.817 & -15.059 \\
Constant & & & $(10.731)$ & $(10.625)$ \\
\hline R-squared & & & $-4.952^{*}$ & $-3.289^{*}$ \\
\hline
\end{tabular}

Wald test for

regime change 


$\begin{array}{lcccc}H_{0}: \delta_{1}=\alpha_{1} & 0.467^{*} & 0.155 & 0.490^{*} & 0.141 \\ & (0.116) & (0.100) & (0.115) & (0.108) \\ H_{0}: \delta_{2}=\alpha_{2} & 0.137 & -0.296^{*} & 0.106 & -0.260^{*} \\ & (0.089) & (0.107) & (0.096) & (0.123) \\ H_{0}: \delta_{3}=\alpha_{3} & & & -18.645 & 31.486^{*} \\ & & & (15.671) & (17.692)\end{array}$

Note: Regime 1 indicates the periods when threshold variable is lower than its HP trend; regime 2 indicates the periods when threshold variable is higher than its HP trend. Threshold variables are current inflation and industrial production level.

In Table 6, the period after the structural break suggests that for the models of inflation gap as the threshold variable, monetary policy does not react significantly to inflation but it does to IP growth in regime 2, that is, higher IP growth is concerned by the policy makers to prevent the deteriorating effects of the expansionary periods. On the other hand, the models of output gap as the threshold variables finds the same results for inflation with the other periods depicted in Table 4 and 5. Nevertheless, the degree of reaction to inflation is way lower compare to the other periods which highlights the distraction of the central bank from inflationary concerns as the period depicts historically low domestic and global prices. For the models of output gap as the threshold variable, IP growth is observed to be a concern when output gap is negative. Finally, for the models of inflation gap as the threshold variable suggest positive reaction to exchange rate deviation when the economy is in the negative inflation gap regime, whereas the reaction to exchange rate, interestingly, is negative for the positive inflation gap period. When we look at the general tendency of the exchange rate given in Figure 3, we observe a significant positive trend after the break point of 2009. However this critical rise does not show its impact on the interest rate given in Figure 5 until the beginning of 2014, the time key interest rate is first increased after the break of 2009. The resistance to exchange rate shows itself in Table 6. 
Table 5: Estimation Results for the asymmetric behavior (2003M01-2009M10)

\begin{tabular}{lcccc}
\hline & \multicolumn{2}{c}{ Model 1 } & \multicolumn{2}{c}{ Model 2 } \\
\hline $\begin{array}{l}\text { Threshold } \\
\text { variable: }\end{array}$ & $\begin{array}{c}\text { inflation } \\
\text { rate }\end{array}$ & IP & inflation rate & IP \\
\hline Regime 1 & & & & \\
\hline Inflation rate & $1.620^{*}$ & $1.415^{*}$ & $1.629^{*}$ & $1.375^{*}$ \\
& $(0.070)$ & $(0.087)$ & $(0.072)$ & $(0.088)$ \\
Annual IP growth & $0.148^{*}$ & $0.162^{*}$ & $0.155^{*}$ & $0.207^{*}$ \\
& $(0.034)$ & $(0.026)$ & $(0.051)$ & $(0.052)$ \\
Exchange rate & & & 2.190 & 9.979 \\
deviation & & & $(7.099)$ & $(7.628)$ \\
\hline
\end{tabular}

Regime 2

\begin{tabular}{lcccc}
\hline Inflation rate & $1.395^{*}$ & $1.314^{*}$ & $1.391^{*}$ & $1.316^{*}$ \\
& $(0.006)$ & $(0.066)$ & $(0.053)$ & $(0.062)$ \\
Annual IP growth & $0.084^{*}$ & $0.190^{*}$ & $0.105^{*}$ & $0.181^{*}$ \\
& $(0.034)$ & $(0.068)$ & $(0.040)$ & $(0.067)$ \\
Exchange rate & & & $12.109^{*}$ & 6.004 \\
deviation & & & $(3.993)$ & $(5.766)$ \\
Constant & $5.385^{*}$ & $6.603^{*}$ & $5.248^{*}$ & $6.731^{*}$ \\
& $(0.693)$ & $(0.852)$ & $(0.681)$ & $(0.861)$ \\
\hline R-squared & 0.92 & 0.90 & 0.92 & 0.90
\end{tabular}

Wald test for 
regime change

$\begin{array}{lcccc}H_{0}: \delta_{1}=\alpha_{1} & 0.225^{*} & 0.101 & 0.239^{*} & 0.059 \\ H_{0}: \delta_{2}=\alpha_{2} & (0.045) & (0.068) & (0.049) & (0.071) \\ & 0.063 & -0.027 & 0.050 & 0.026 \\ H_{0}: \delta_{3}=\alpha_{3} & (0.048) & (0.076) & (0.065) & (0.088) \\ & & & -9.918 & 3.975 \\ & & & (8.229) & (9.543)\end{array}$

Note: Regime 1 indicates the periods when threshold variable is lower than its HP trend; regime 2 indicates the periods when threshold variable is higher than its HP trend. Threshold variables are current inflation and industrial production level.

Table 6: Estimation Results for the asymmetric behavior (2009M11-2016M04)

\begin{tabular}{|c|c|c|c|c|}
\hline & & & & \\
\hline $\begin{array}{l}\text { Threshold } \\
\text { variable: }\end{array}$ & $\begin{array}{c}\text { inflation } \\
\text { rate }\end{array}$ & IP & inflation rate & IP \\
\hline Regime 1 & & & & \\
\hline & 0.144 & $0.224 *$ & 0.081 & $0.233^{*}$ \\
\hline & $(0.200)$ & $(0.105)$ & $(0.209)$ & $(0.114)$ \\
\hline & 0.018 & $0.056^{*}$ & 0.012 & $0.059 *$ \\
\hline & $(0.038)$ & $(0.031)$ & $(0.037)$ & $(0.032)$ \\
\hline Exchange rate & & & $10.614 *$ & 2.656 \\
\hline deviation & & & (4.930) & $(5.802)$ \\
\hline Regime 2 & & & & \\
\hline $\mathrm{I} \cdot \mathrm{C}$ & 0.121 & $0.189 *$ & 0.066 & $0.195^{*}$ \\
\hline 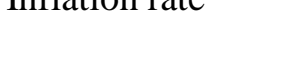 & $(0.165)$ & $(0.113)$ & $(0.165)$ & $(0.118)$ \\
\hline & $0.087 *$ & 0.047 & $0.088^{*}$ & 0.052 \\
\hline Annual If growtn & $(0.036)$ & $(0.036)$ & $(0.030)$ & $(0.036)$ \\
\hline Exchange rate & & & $-14.141 *$ & -4.047 \\
\hline deviation & & & (5.400) & (4.816) \\
\hline Comptor & 5.521 & $4.941 *$ & $6.000 *$ & $4.857 *$ \\
\hline - & $(1.481)$ & $(0.876)$ & $(1.561)$ & $(0.952)$ \\
\hline
\end{tabular}




\begin{tabular}{lcccc}
\hline R-squared & 0.09 & 0.09 & 0.21 & 0.10 \\
Wald test for & & & & \\
regime change & & & & \\
$H_{0}: \delta_{1}=\alpha_{1}$ & 0.023 & 0.034 & 0.015 & 0.038 \\
& $(0.071)$ & $(0.061)$ & $(0.069)$ & $(0.061)$ \\
$H_{0}: \delta_{2}=\alpha_{2}$ & -0.069 & 0.009 & -0.076 & 0.006 \\
& $(0.052)$ & $(0.045)$ & $(0.047)$ & $(0.046)$ \\
$H_{0}: \delta_{3}=\alpha_{3}$ & & & $24.754 *$ & 6.703 \\
\end{tabular}

Note: Regime 1 indicates the periods when threshold variable is lower than its HP trend; regime 2 indicates the periods when threshold variable is higher than its HP trend. Threshold variables are current inflation and industrial production level.

Following the break date suggested by the two breakpoint tests for the Taylor rule model, we will split the dataset entered in the DSGE estimation model in the following section accordingly, although the dataset employed has quarterly frequency.

\section{Theoretical Model}

The small-size open economy New Keynesian DSGE model is estimated for Turkey based on Justiniano and Preston (2010).

\subsection{Households}

In the model, the household maximizes the following utility function where $C_{t}, N_{t}$ and $H_{t}$ denotes consumption, labor and habit formation, successively. Habit is determined by the lagged value of consumption.

$$
E_{0} \sum_{t=0}^{\infty} \beta^{t} \mathrm{E}_{g, t}\left[\left(\frac{C_{t}-h C_{t-1}}{1-\sigma}\right)^{1-\sigma}-\left(\frac{N_{t}}{1-\varphi}\right)^{1-\varphi}\right]
$$


where $0<\beta<1$ is discount rate; $\sigma>0$ is the inverse intertemporal elasticity of substitution; $\varphi>0$ is the inverse Frisch; $h$ is the habit formation parameter and $\mathrm{E}_{g, t}$ is the preference shock. Consumption, $C_{t}$, is a composite index that includes domestic, $C_{H, t}$, and foreign consumption, $C_{F, t}$, as follows:

$$
\begin{gathered}
C_{t}=\left[(1-\alpha)^{\frac{1}{\eta}} C_{H, t}^{\frac{\eta-1}{\eta}}+\alpha^{\frac{1}{\eta}} C_{F, t}^{\frac{\eta-1}{\eta}}\right]^{\frac{\eta}{\eta-1}} \\
C_{H, t}=\left[\int_{0}^{1} C_{H, t}(i)^{\frac{\varepsilon-1}{\varepsilon}} d i\right]^{\frac{\varepsilon}{\varepsilon-1}} \text { and } C_{F, t}=\left[\int_{0}^{1} C_{F, t}(i)^{\frac{\varepsilon-1}{\varepsilon}} d i\right]^{\frac{\varepsilon}{\varepsilon-1}}
\end{gathered}
$$

where $\alpha$ is the openness parameter; $\eta>0$ is the elasticity of substitution between foreign and domestic goods.

\section{2. $\quad$ Firms}

There is a continuum of identical monopolistically firms, each of which produces a differentiated good. Hence, nominal rigidity is introduced where a fraction, $\theta_{H}$ and $\theta_{F}$, of the domestic and foreign firms do not reoptimize their prices. Hence, firms face a Calvo (1983) price setting problem. The Dixit-Stiglitz aggregate price index for the domestic economy is as follows.

$$
P_{H, t}=\left[\left(1-\theta_{H}\right) P_{H, t}^{1-\varepsilon}+\theta_{H}\left(P_{H, t-1}^{1-\varepsilon}\left(\frac{P_{H, t-1}}{P_{H, t-2}}\right)^{\delta_{H}}\right)^{1-\varepsilon}\right]^{\frac{1}{1-\varepsilon}}
$$

For their price-setting problem, domestic firms maximize their expected present discounted value of profits given as follows:

$$
E_{0} \sum_{s=0}^{\infty} \theta_{H}^{s} Q_{t, t+s} Y_{H, t+s}(i)\left[\left(P_{H, t}(i) \frac{P_{H, t+s-1}}{P_{H, t-1}}\right)^{\delta_{H}}-P_{H, t+s} M C_{H, t+s}\right]
$$


subject to the demand curve

$$
Y_{H, t+s}(i)=\left[\frac{P_{H, t}(i)}{P_{H, t+s}}\left(\frac{P_{H, t+s-1}}{P_{H, t-1}}\right)^{\delta_{H}}\right]^{-\varepsilon}\left(C_{H, t+s}+C_{H, t+s}^{*}\right)
$$

and

$$
M C_{H, t}=\frac{W_{t}}{P_{H, t} \mathrm{E}_{a, t}}
$$

where $\varepsilon$ is the elasticity of substitution between produced goods; $M C_{H, t}$ is the real marginal cost; $\mathrm{E}_{a, t}$ is the exogenous technology shock.

The idea for the importing firms is basically the same as domestic firms with the following relation.

$$
P_{F, t}=\left[\left(1-\theta_{F}\right) P_{F, t}^{1-\varepsilon}+\theta_{F}\left(P_{F, t-1}^{1-\varepsilon}\left(\frac{P_{F, t-1}}{P_{F, t-2}}\right)^{\delta_{F}}\right)^{1-\varepsilon}\right]^{\frac{1}{1-\varepsilon}}
$$

Expected present discounted value of profits and the demand curve is constructed in a similar pattern to domestic firms.

\subsection{Terms of trade, real exchange rate and general equilibrium}

In equilibrium, domestically produced output is equal to the total domestic demand, which includes domestic and foreign demand. 


$$
Y_{H, t}=C_{H, t}+C_{H, t}^{*}
$$

Terms of trade is defined as ratio of price of imports to price of home goods as follows:

$$
S_{t}=\frac{P_{F, t}}{P_{H, t}}
$$

Real exchange rate is defined as the ratio of world currency price index expressed in terms of domestic currency to home country's price index.

$$
\Theta_{t}=\frac{X R_{t} P_{t}^{*}}{P_{t}}
$$

\subsection{Log-linearized model $^{\mathrm{a}}$}

$\mathrm{c}_{\mathrm{t}}-\mathrm{hc}_{\mathrm{t}-1}=E_{t}\left(\mathrm{c}_{\mathrm{t}+1}-\mathrm{hc}_{\mathrm{t}}\right)-\sigma^{-1}(1-h)\left(i_{t}-E_{t} \pi_{\mathrm{t}+1}-\varepsilon_{\mathrm{g}, \mathrm{t}}+E_{t} \varepsilon_{\mathrm{g}, \mathrm{t}+1}\right)$

$(1-\alpha) c_{t}-y_{t}=\alpha \eta(2-\alpha) s_{t}-\alpha \eta \psi_{F, t}-\alpha y_{t}^{*}$

$\psi_{F, t}=e_{t}+p_{t}^{*}-p_{F, t}$

$\Delta s_{\mathrm{t}}=\pi_{F, t}-\pi_{H, t}$

$\Delta q_{\mathrm{t}}=\Delta e_{t}+\pi_{t}^{*}-\pi_{t}$

$\pi_{H, t}=\delta \pi_{H, t-1}+\frac{\left(1-\theta_{H}\right)}{\theta_{H}}\left(1-\theta_{H} \beta\right)\left(\varphi_{t} y_{t}-(1+\varphi) \varepsilon_{a, t}+\alpha s_{t}+\frac{\sigma}{1-h}+\left(c_{t}-h c_{t-1}\right)\right)+\beta E_{t}\left(\pi_{H, t+1}-\delta \pi_{H, t}\right)$

$\pi_{F, t}=\delta \pi_{F, t-1}+\frac{\left(1-\theta_{F}\right)}{\theta_{F}}\left(1-\theta_{F} \beta\right) \psi_{F, t}+\beta E_{t}\left(\pi_{F, t+1}-\delta \pi_{F, t}\right)+\varepsilon_{c p, t}$

${ }^{a}$ Small letters are log-linearized variables of capital letters. 
$\pi_{t}=\pi_{H, t}+\alpha \Delta s_{t}$

$\left(i_{t}-E_{t} \pi_{t+1}\right)-i_{t}^{*}-E_{t} \pi_{t+1}^{*}=E_{t} \Delta q_{t+1}-\chi a_{t}+\phi_{t}$

$c_{t}+a_{t}=\frac{1}{\beta} a_{t-1}-\alpha\left(s_{t}+\psi_{F, t}\right)+y_{t}$

$i_{t}=\rho_{i} i_{t-1}+\psi_{\pi} \pi_{t}+\psi_{y} y_{t}+\psi_{e} e_{t}+\varepsilon_{M, t}$
(a) Euler equation
(b) Market Clearing
(c) Law of One Price Gap
(d) Terms of trade
(e) Change in the nominal exchange rate
(f) Domestic price inflation
(g) Import price inflation
(h) Domestic CPI inflation
(i) Uncovered interest parity condition
(j) Foreign asset budget constraint
(k) Monetary policy rule

And exogenous $\operatorname{AR}(1)$ processes for preference $\left(\varepsilon_{\mathrm{g}, \mathrm{t}}\right)$, technology $\left(\varepsilon_{\mathrm{a}, \mathrm{t}}\right)$, import cost push $\operatorname{shock}\left(\varepsilon_{\mathrm{cp}, \mathrm{t}}\right)$ and risk premium shock $\left(\phi_{\mathrm{t}}\right)$ with autoregressive coefficients $\rho_{g}, \rho_{a}, \rho_{c p}$ and $\rho_{\phi}$, respectively. $\operatorname{VAR}(2)$ is defined for $\pi_{t}^{*}, y_{t}^{*}$ and $i_{t}^{*}$.

\section{ESTIMATION}

Parameters of the model are estimated via Bayesian Maximum Likelihood Estimator (MLE). Bayesian method makes conditional probabilistic statements regarding the parameters of the DSGE using a priori distribution. Before looking at the data, the researcher may introduce a prior density function for the parameter. In this approach, the prior distribution is combined 
with the data and posterior distributions are obtained. Hence, instead of producing a point estimate, a Bayesian analysis produces posterior density function. Posterior density function is a weighted average of the prior density and the likelihood.

Prior distributions should be specified considering the restrictions of the parameters. There are several distributions with different domains:

- For positive parameters, gamma distribution,

- For parameters constrained on the unit interval, beta distribution,

- For unconstrained parameters, normal distribution,

- For shocks, inverse gamma distribution is used.

Both models are estimated using Dynare under Matlab. Metropolis-Hastings (MH) using Kalman filter with 100,000 draws and 5 parallel chains for MH algorithm.

\subsection{Data and Calibration}

The model is estimated using 8 variables since there are 8 shocks to the system ${ }^{\mathrm{b}}$. The data period is between 2002Q1 to 2015Q4. The dataset is split into two periods as the break tests suggest. Hence, the data period is between 2002Q1 to 2009Q3 for period 1 and between 2009Q4 to 2015Q4 for period 2. The foreign dataset is selected from the US. Real exchange rate is calculated as the ratio of US CPI times nominal exchange rate (TL/\$) to Turkish CPI. Terms of trade is defined as the ratio of import price to export price where both are calculated as the ratio of the relevant deflator. Both inflation rates are annual changes in CPI of the relevant country. Interest rate of Turkey is the policy rate which is overnight rate before 2010 May and 1-week repo after that period. US interest rate is federal funds rate. GDP of both countries are detrended logarithmically. Real exchange rate and terms of trade are in logarithmic difference.

The calibrated parameters are discount rate, which is calibrated as 0.99 , country risk, which is calibrated as 0.01. Both parameters are adopted from the relevant literature. Openness parameter is calibrated as the ratio of imports plus exports to GDP. For the first period, it is calibrated as 0.51 and for the second period as 0.54 .

\footnotetext{
${ }^{b}$ The number of shocks and variables observed should be equal to each other for full-identification.
} 
In the literature there exists New Keynesian DSGE models for Turkey. Çebi (2012) utilizes a New Keynesian DSGE model for Turkey over the period of 2002Q1-2009Q3. Using Bayesian estimation, he suggests that monetary policy regarding inflation is 1.75 and output gap is 0.41 , that is monetary authority reacts to inflation but only weakly reacts to the output gap. On the other hand, Ortiz et al. (2009) examine DSGE model for Turkey splitting the dataset. They observe that parameters on inflation are 1.19 and 1.77 for the period 1989:Q2-1993:Q4 and 1989:Q2-1998:Q1, respectively. In the same manner, output gap parameters are 0.17 and 0.20 .

\subsection{Results}

As observed in Table 7 and 8, the interest rate smoothing parameter declines from 0.87 in period 1 to 0.84 in period 2, reflecting that the interest rate is relatively less persistent in period 2. The parameter we highly focus on is the parameter of inflation in Taylor rule. The estimation suggests that the parameter has declined from 2.24 in period 1 to 2.14 in period 2 . The decline is relatively smaller compared to OLS estimation run in single equation model. Exchange rate parameter in Taylor rule also suggests a decline from 0.62 to 0.56. Similarly, output parameter in Taylor rule declines from 0.34 to 0.32 .

\section{Table 7: Prior and posterior estimates for Period 1}

\begin{tabular}{clcccccc} 
Parameter & Description & $\begin{array}{c}\text { Prior } \\
\text { Density }\end{array}$ & $\begin{array}{c}\text { Prior } \\
\text { Mean }\end{array}$ & SD & $\begin{array}{c}\text { Posterior } \\
\text { Mean }\end{array}$ & \multicolumn{2}{c}{ 90\% CI } \\
\hline$\alpha$ & Openness parameter & - & 0.51 & - & - & - & - \\
$\beta$ & Discount rate & - & 0.99 & - & - & - & - \\
$\chi$ & Country risk & - & 0.01 & - & - & - & - \\
$\sigma$ & Inverse interremporal elasticity of & $\mathrm{N}$ & 3.00 & 0.75 & 1.92 & 0.92 & 2.90 \\
$\varphi$ & lubstitution & N & 2.00 & 0.50 & 2.13 & 1.36 & 2.89 \\
$\theta_{H}$ & Calvo domestic prices & $\mathrm{B}$ & 0.50 & 0.20 & 0.87 & 0.82 & 0.93 \\
$\theta_{F}$ & Calvo import prices & $\mathrm{B}$ & 0.50 & 0.20 & 0.19 & 0.13 & 0.25 \\
$\eta$ & Elasticity of substitution between H and F & $\mathrm{G}$ & 0.70 & 0.10 & 0.78 & 0.62 & 0.95 \\
$h$ & Habit formation & $\mathrm{B}$ & 0.50 & 0.25 & 0.12 & 0.00 & 0.24 \\
$\delta_{H}$ & Indexation domestic & $\mathrm{B}$ & 0.80 & 0.10 & 0.68 & 0.46 & 0.92 \\
$\delta_{F}$ & Indexation foreign & $\mathrm{B}$ & 0.80 & 0.10 & 0.83 & 0.70 & 0.96 \\
$\psi_{i}$ & Lagged interest rate in Taylor rule & $\mathrm{B}$ & 0.50 & 0.25 & 0.87 & 0.74 & 1.00 \\
$\psi_{\pi}$ & Taylor rule, inflation & $\mathrm{G}$ & 1.50 & 0.30 & 2.24 & 1.59 & 2.87
\end{tabular}




$\begin{array}{llllllll}\psi_{e} & \text { Taylor rule, exchange rate change } & \mathrm{G} & 0.25 & 0.13 & 0.62 & 0.22 & 1.01 \\ \psi_{y} & \text { Taylor rule, output growth } & \mathrm{G} & 0.25 & 0.13 & 0.34 & 0.11 & 0.58 \\ \rho_{a} & \text { Persistence of technology shock } & \mathrm{B} & 0.80 & 0.10 & 0.67 & 0.46 & 0.87 \\ \rho_{g} & \text { Persistence of preference shock } & \mathrm{B} & 0.80 & 0.10 & 0.67 & 0.48 & 0.86 \\ \rho_{\phi} & \text { Persistence of risk premium shock } & \mathrm{B} & 0.80 & 0.10 & 0.74 & 0.63 & 0.86 \\ \rho_{c p} & \text { Persistence of import cost-push shock } & \mathrm{B} & 0.50 & 0.25 & 0.74 & 0.53 & 0.98 \\ \sigma_{\pi^{*}} & \text { St. dev. foreign inf. Shock } & \mathrm{I} & 0.50 & 0.25 & 0.16 & 0.12 & 0.19 \\ \sigma_{y^{*}} & \text { St. dev. foreign output shock } & \mathrm{I} & 0.50 & 0.25 & 0.16 & 0.12 & 0.19 \\ \sigma_{i^{*}} & \text { St. dev. foreign int. rate shock } & \mathrm{I} & 0.50 & 0.25 & 0.18 & 0.14 & 0.21 \\ \sigma_{a} & \text { St. dev. technology shock } & \mathrm{I} & 0.50 & 0.25 & 0.59 & 0.29 & 0.91 \\ \sigma_{m} & \text { St. dev. monetary shock } & \mathrm{I} & 0.50 & 0.25 & 0.16 & 0.13 & 0.20 \\ \sigma_{g} & \text { St. dev. preference shock } & \text { I } & 0.50 & 0.25 & 0.52 & 0.29 & 0.74 \\ \sigma_{\phi} & \text { St. dev. risk premium shock } & \mathrm{I} & 0.50 & 0.25 & 0.18 & 0.14 & 0.22 \\ \sigma_{c p} & \text { St. dev. import cost-push shock } & \mathrm{I} & 0.50 & 0.25 & 0.28 & 0.18 & 0.38\end{array}$

Note: The posterior distributions are obtained using the Metropolis-Hastings algorithm. Estimations are done with Dynare version 4.2.4 in MATLAB (http://www.dynare.org/download)

\section{Table 8: Prior and posterior estimates for Period 2}

\begin{tabular}{|c|c|c|c|c|c|c|c|}
\hline Parameter & Description & $\begin{array}{l}\text { Prior } \\
\text { Density }\end{array}$ & $\begin{array}{l}\text { Prior } \\
\text { Mean }\end{array}$ & SD & $\begin{array}{l}\text { Posterior } \\
\text { Mean }\end{array}$ & \multicolumn{2}{|c|}{ 90\% CI } \\
\hline$\alpha$ & Openness parameter & - & 0.54 & - & - & - & - \\
\hline$\beta$ & Discount rate & - & 0.99 & - & - & - & - \\
\hline$\chi$ & Country risk & - & 0.01 & - & - & - & - \\
\hline$\sigma$ & $\begin{array}{l}\text { Inverse intertemporal elasticity of } \\
\text { substitution }\end{array}$ & $\mathrm{N}$ & 3.00 & 0.75 & 2.52 & 1.59 & 3.54 \\
\hline$\varphi$ & Inverse Frisch & $\mathrm{N}$ & 2.00 & 0.50 & 2.07 & 1.27 & 2.82 \\
\hline$\theta_{H}$ & Calvo domestic prices & B & 0.50 & 0.20 & 0.81 & 0.74 & 0.88 \\
\hline$\theta_{F}$ & Calvo import prices & B & 0.50 & 0.20 & 0.16 & 0.09 & 0.22 \\
\hline$\eta$ & Elasticity of substitution between $\mathrm{H}$ and $\mathrm{F}$ & G & 0.70 & 0.10 & 0.79 & 0.62 & 0.95 \\
\hline$h$ & Habit formation & B & 0.50 & 0.25 & 0.13 & 0.00 & 0.26 \\
\hline$\delta_{H}$ & Indexation domestic & B & 0.80 & 0.10 & 0.74 & 0.55 & 0.94 \\
\hline$\delta_{F}$ & Indexation foreign & B & 0.80 & 0.10 & 0.80 & 0.65 & 0.96 \\
\hline$\psi_{i}$ & Lagged interest rate in Taylor rule & B & 0.50 & 0.25 & 0.84 & 0.67 & 1.00 \\
\hline$\psi_{\pi}$ & Taylor rule, inflation & G & 1.50 & 0.30 & 2.14 & 1.51 & 2.76 \\
\hline$\psi_{e}$ & Taylor rule, exchange rate change & G & 0.25 & 0.13 & 0.56 & 0.17 & 0.95 \\
\hline$\psi_{y}$ & Taylor rule, output growth & G & 0.25 & 0.13 & 0.32 & 0.08 & 0.57 \\
\hline$\rho_{a}$ & Persistence of technology shock & $\mathrm{B}$ & 0.80 & 0.10 & 0.67 & 0.47 & 0.89 \\
\hline
\end{tabular}




\begin{tabular}{llllllll}
$\rho_{g}$ & Persistence of preference shock & B & 0.80 & 0.10 & 0.69 & 0.50 & 0.89 \\
$\rho_{\phi}$ & Persistence of risk premium shock & B & 0.80 & 0.10 & 0.59 & 0.42 & 0.76 \\
$\rho_{c p}$ & Persistence of import cost-push shock & B & 0.50 & 0.25 & 0.61 & 0.32 & 0.92 \\
$\sigma_{\pi^{*}}$ & St. dev. foreign inf. Shock & I & 0.50 & 0.25 & 0.17 & 0.13 & 0.21 \\
$\sigma_{y^{*}}$ & St. dev. foreign output shock & I & 0.50 & 0.25 & 0.17 & 0.13 & 0.21 \\
$\sigma_{i^{*}}$ & St. dev. foreign int. rate shock & I & 0.50 & 0.25 & 0.18 & 0.14 & 0.22 \\
$\sigma_{a}$ & St. dev. technology shock & I & 0.50 & 0.25 & 0.40 & 0.23 & 0.58 \\
$\sigma_{m}$ & St. dev. monetary shock & I & 0.50 & 0.25 & 0.18 & 0.14 & 0.22 \\
$\sigma_{g}$ & St. dev. preference shock & I & 0.50 & 0.25 & 0.43 & 0.26 & 0.58 \\
$\sigma_{\phi}$ & St. dev. risk premium shock & I & 0.50 & 0.25 & 0.19 & 0.14 & 0.23 \\
$\sigma_{c p}$ & St. dev. import cost-push shock & I & 0.50 & 0.25 & 0.34 & 0.19 & 0.48 \\
\hline
\end{tabular}

\section{Conclusion}

This paper examines the asymmetric reaction and structural breaks for the monetary policy of CBT for the 2003-2016 period. The break tests suggests existence of a structural change after 2009 October which can be referred as global financial crisis and the period is also observed to include historically low world prices and domestic prices in Turkey. The asymmetric models regarding inflation gap and output gap suggest that monetary policy makers are more concerned with the less inflationary periods which can be attributed to the data period selected (which concentrates on the period right after inflation targeting policy) and the historical success of managing lower inflation rates.. This finding is opposite to the general empirical findings in the literature. Another surprising result is the resistance of the monetary policy to the rising exchange rate after 2009. Also a very basic small open economy DSGE model is estimated for Turkey using quarterly dataset. The estimation suggests a consistent decline in all parameters from period 1 to period 2. However, the decline in the impact of inflation is relatively lower is the DSGE model compared to the single equation OLS model. 


\section{References}

Alp, H., Gürkaynak, R., Kara, H., Keleş, G., \& Orak, M. (2010). Türkiye’de piyasa göstergelerinden para politikası beklentilerinin ölçülmesi. İktisat İşletme ve Finans, 25(295), $21-45$.

Andrews, D. W., 1993. Tests for parameter instability and structural change with unknown change point. Econometrica: Journal of the Econometric Society, 821-856.

Andrews, D. W., and Ploberger, W., 1994. Optimal tests when a nuisance parameter is present only under the alternative. Econometrica: Journal of the Econometric Society, 1383-1414.

Bai, J., 1997. Estimation of a change point in multiple regression models. Review of Economics and Statistics, 79(4), 551-563.

Bai, J., and Perron, P., 1998. Estimating and testing linear models with multiple structural changes. Econometrica, 47-78.

Bec, F., M.B. Salem, F. Collard, 2002. "Asymmetries in monetary policy reaction function: Evidence for the US, French and German central banks", Studies in Nonlinear Dynamics and Econometrics, Vol. 6(2), pp. 1-22. 
Benlialper, A. Cömert, H., Öcal, N., 2015. “Asymmetric Exchange Rate Policy in Inflation Targeting Developing Countries", mimeo.

http://www.boeckler.de/pdf/v_2015_10_23_benlialper.pdf, Accessed 12 December 2016.

Berument, H., 2007. Measuring monetary policy for a small open economy: Turkey, Journal of Macroeconomics, Vol. 29, pp. 411-430.

Berument, H. K. Malatyali, 2000. The implicit reaction function of the Central Bank of Republic of Turkey, Applied Economics Letters, Vol. 7, pp. 425-430.

Binici, M., Kara, H., and Ozlu, P., 2016. Faiz Koridoru ve Banka Faizleri: Parasal Aktarim Mekanizmasina Dair Bazi Bulgular, Central Bank of Republic of Turkey Working Papers, No. 1608.

Calvo, G. A. (1983). Staggered prices in a utility-maximizing framework. Journal of monetary Economics, 12(3), 383-398.

Chow, G. C., 1960. Tests of equality between sets of coefficients in two linear regressions. Econometrica: Journal of the Econometric Society, 591-605.

Çebi, C., 2012. The interaction between monetary and fiscal policies in Turkey: An estimated New Keynesian DSGE model. Economic Modelling, Vol. 29 (4), pp. 1258-1267.

Geyik, E. Ü., 2011. A test for asymmetric central bank preferences in Turkey, Internatıonal Journal Of Social Sciences And Humanity Studies, Vol 3 (2), pp. 179-191.

Gürkaynak, R. S., Kantur, Z., Taş, M. A., \& Yıldırım, S. (2015). Monetary policy in Turkey after Central Bank independence, 30(356), 9-38.

Hasanov, M., and Omay, T., 2008. Monetary policy rules in practice: Re-examining the case of Turkey. Physica A: Statistical Mechanics and its Applications, 387(16), 4309-4318.

Hasanov, M., and Omay, T., 2008. Nonlinearities in emerging stock markets: evidence from Europe's two largest emerging markets. Applied Economics, 40(20), 2645-2658.

Justiniano, A., and Preston, B., 2010. Monetary policy and uncertainty in an empirical small open-economy model. Journal of Applied Econometrics, 25(1), 93-128.

Klose, J., 2011. Asymmetric Taylor reaction functions of the ECB: An approach depending on the state of the economy. The North American Journal of Economics and Finance, 22(2), 149-163. 
Komlan, F. (2013). The asymmetric reaction of monetary policy to inflation and the output gap: evidence from Canada. Economic Modelling, 30, 911-923.

Ortiz, A., Ottonello, P., Sturzenegger, F., \& Talvi, E. (2009). Monetary and fiscal policies in a sudden stop: Is tighter brighter?

Quandt, R. E., 1960. Tests of the hypothesis that a linear regression system obeys two separate regimes. Journal of the American statistical Association, 55(290), 324-330.

Surico, P. (2003). Asymmetric reaction functions for the euro area. Oxford Review of Economic Policy, 19(1), 44-57.

Sznajderska, A., 2014. Asymmetric effects in the Polish monetary policy rule. Economic Modelling, 36, 547-556.

Taylor, J. B. (1993, December). Discretion versus policy rules in practice. In CarnegieRochester conference series on public policy (Vol. 39, pp. 195-214). North-Holland.

Ülke, V. and Berument, M. H., 2016. Asymmetric effects of monetary policy shocks on economic performance: empirical evidence from Turkey. Applied Economics Letters, 23(5), 353-360.

Vasicek, B., 2012. Is monetary policy in new member states asymmetric? Econ. Syst. 36 (2), 235-263.

\section{Appendix}

Figure 1: Turkish GDP growth rate and CPI inflation rate (Annual)

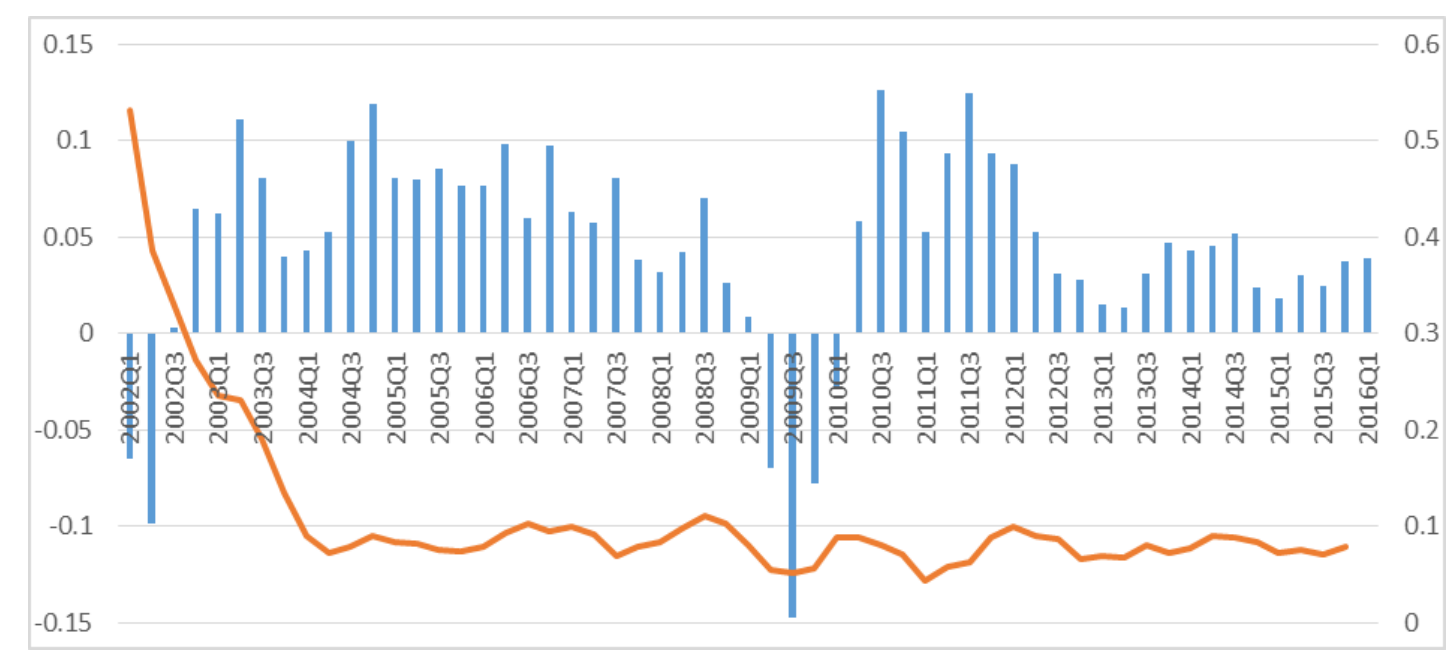

Note: GDP growth rate (annual) is shown on the left axis with bars whereas CPI inflation rate (annual) is shown on the right-axis with line. 
Figure 2: Turkish annual export (thousand TL) in 1998 constant prices

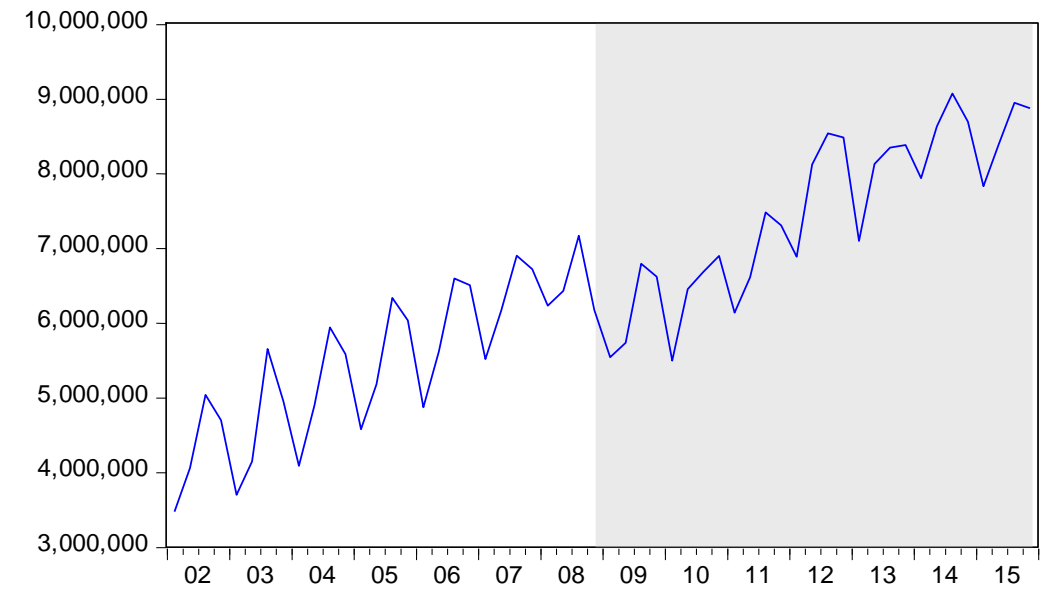

Note: Shaded area starts from 2008Q4.

Figure 3: Exchange rate US/TL between 2002 January-2016 June

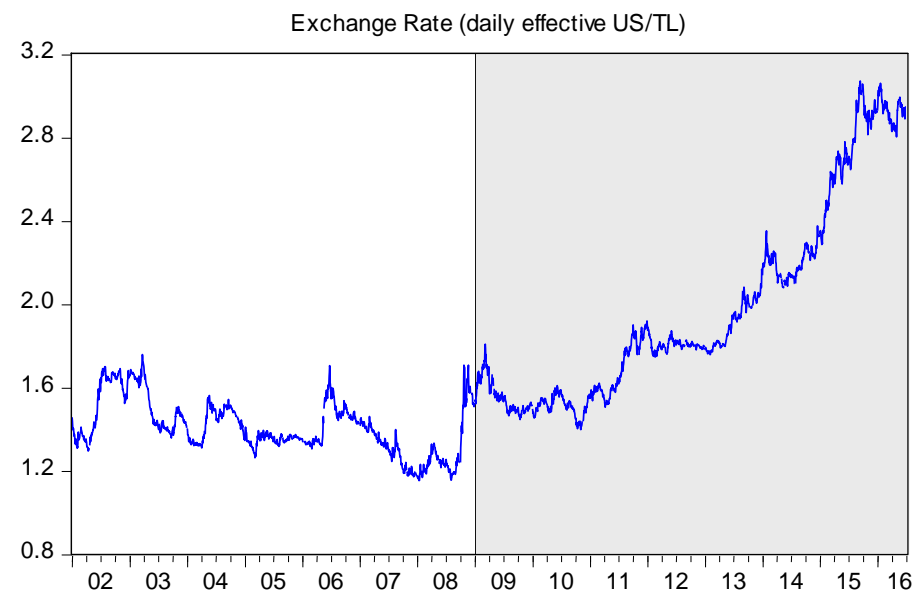

Note: After 2009 period is depicted by shaded area.

Figure 4: US annual CPI inflation rate (compared to same quarter of the previous year) 


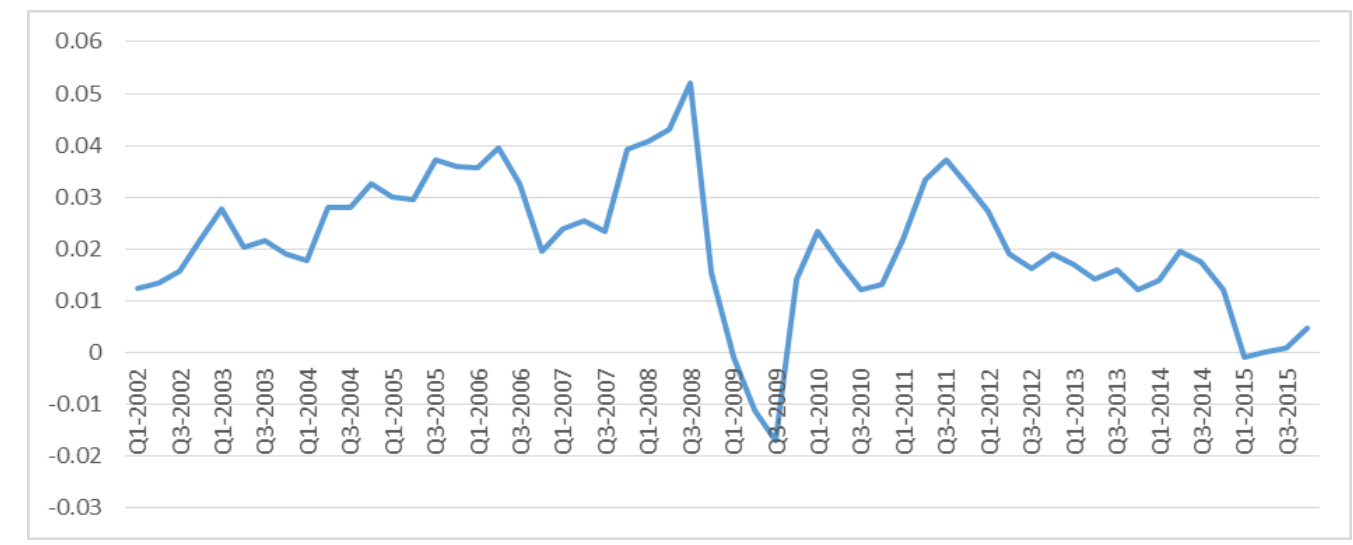

Figure 5: Turkey Policy Rate and GDP level (in quarterly frequency)

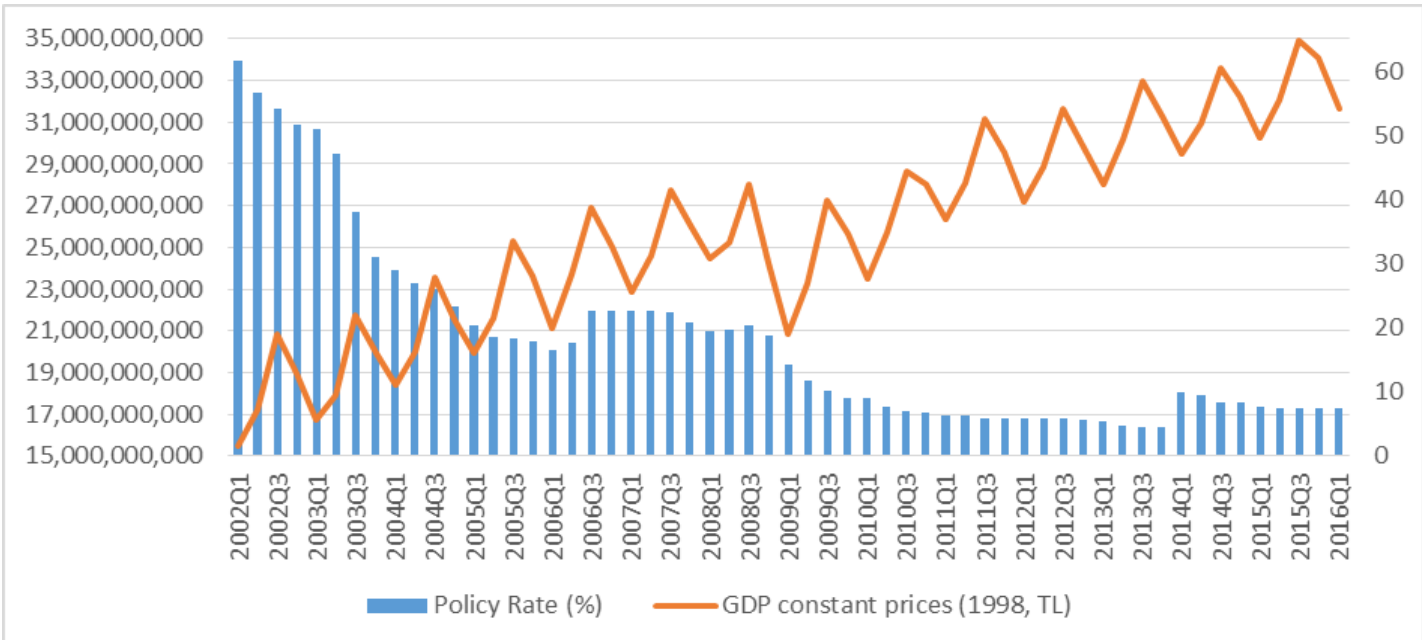

Note: Policy rate is shown in the right-hand-side axis. 